\title{
Editorial:
}

\section{El Derecho a la Educación es el Derecho a una Educación Inclusiva y Equitativa}

\section{The Right to Education is the Right to an Inclusive and Equitable Education}

\author{
Cynthia Duk ${ }^{1 *}$ \\ F. Javier Murillo 2 \\ ${ }^{1}$ Universidad Central de Chile, Chile \\ ${ }^{2}$ Universidad Autónoma de Madrid, España
}

Ha transcurrido más de medio año desde que escribimos unas breves palabras a modo de editorial del número 14(1) de la Revista Latinoamericana de Educación Inclusiva que titulamos "El Covid-19 y las Brechas Educativas" (Murillo y Duk, 2020), y el panorama mundial de la educación a causa de la pandemia se ha mantenido prácticamente igual. En América Latina y el Caribe, debido a las medidas de confinamiento y distanciamiento social adoptadas para contener la propagación del virus, las escuelas siguen cerradas y con ello las clases presenciales suspendidas. Dadas las medidas sanitarias que se requieren, que en muchos casos las escuelas difícilmente podrán afrontar, especialmente en contextos de escasos recursos, varios países de la región han decidido que las escuelas permanezcan cerradas hasta fines de este año escolar y no se tiene certeza de su reapertura a comienzos del próximo. Hoy por hoy, la máxima prioridad en todos los países es garantizar un retorno seguro a las aulas; a partir de ahí, en algunos territorios se está apostando por un retorno gradual, voluntario, acordado y preparado con la participación de las comunidades escolares.

Ante la complejidad de esta crisis sin precedentes, hemos de reconocer que los diferentes sistemas educativos han realizado importantes esfuerzos para mitigar los efectos de la interrupción del aprendizaje y continuar a la enseñanza a través de la combinación de distintas modalidades de educación a distancia, uso de plataformas digitales, de dispositivos de comunicación instantánea y redes sociales, así como de programas educativos a través de la televisión y la radio de larga tradición en la región. No obstante, no deja de ser paradójico que al tiempo que se disponen de mayores recursos e innovaciones tecnológicas para expandir las oportunidades y apoyar el aprendizaje, éstas no son accesibles a todos y todas, exacerbando las inequidades y la exclusión de los grupos más desfavorecidos.

La UNESCO acaba de lanzar la edición para América Latina y el Caribe del Informe de Seguimiento de la Educación en el Mundo -Informe GEM 2020- con el sugerente título de "Inclusión y Educación: Todos y Todas sin Excepción" (UNESCO, 2020). En el mismo se destaca que, siendo Latinoamérica y el Caribe la Región más desigual del mundo, existen temores fundados que tras la pandemia los avances alcanzados en las últimas décadas en materia de universalización y equidad se vean mermados. Ello podría

*Contacto: cduk@ucentral.cl 
producirse, entre otros factores, como consecuencia de la desbastadora recesión económica que, según estimaciones del Fondo Monetario Internacional, podría llegar a que el PIB del conjunto de la región se contraiga este año en un 9,3\%.

Los datos que aporta el informe GEM 2020 son sin duda impactantes. Por nombrar algunos, la crisis sanitaria en su punto más alto obligó a más de 160 millones de niños, niñas y adolescentes a dejar la escuela, amenazando sus derechos a la educación, la protección y bienestar. Antes de la pandemia había 12 millones de niños y niñas no escolarizados en la Región. La preocupación actual es cuántos más habrá una vez que pase la crisis, especialmente porque se sabe que cuanto más tiempo los estudiantes permanecen desvinculados de la escuela, mayor es el riesgo de que no regresen, especialmente en el caso de los más vulnerables. En ese sentido, nos advierte que es muy probable que la deserción se acreciente particularmente en los dos extremos de la trayectoria educativa, en la educación inicial y en el segundo ciclo de la secundaria, agudizando las desigualdades. La UNESCO estima que es posible que un $2,3 \%$ de los estudiantes que se encuentran cursando el último ciclo de secundaria abandonen. Si esta estimación se cruza con que bajo condiciones normales, como el mismo informe GEM indica, solo el 63\% de los estudiantes de la Región finaliza la secundaria y que aquellos que pertenecen al $20 \%$ más rico tienen cinco veces más probabilidades de concluir sus estudios que los del $20 \%$ más pobre. Desde el punto de vista del aprendizaje, la mayoría de los y las jóvenes que cursan modalidades de Educación Técnico Profesional en la Región provienen de los sectores de menores ingresos y, por tanto, son nuevamente los que más resentirán el impacto de la falta de formación práctica para el desarrollo de las competencias de especialidad, elemento fundamental de la formación en esta modalidad que exige presencialidad.

Los datos del informe GEM muestran que la región ha logrado extender la educación a distancia muy por encima del promedio mundial, lo cual no deja de ser alentador en la situación actual, aun cuando sabemos que las soluciones a distancia no sustituyen la experiencia educativa que resulta de la interacción directa entre los estudiantes y de estos con sus docentes. Las escuelas, en su rol social, cumplen diversas funciones además de proporcionar educación, ofrecen resguardo y diversos apoyos a los estudiantes, en particular a los más necesitados, y son un espacio de encuentro y convivencia en la diversidad, crucial para el pleno desarrollo personal y la construcción de una ciudadanía democrática e inclusiva. En este sentido, si algo positivo ha tenido esta crisis es que ha puesto de relieve el rol insustituible que cumple la escuela en nuestras sociedades, revalorizando su importancia.

Continuando esta mirada forzosamente optimista, otro elemento esperanzador que ha tenido esta crisis es que ha acelerado de manera masiva la incorporación de las nuevas tecnologías a la educación, instalando mayores capacidades en los sistemas educativos para su uso como herramienta pedagógica de apoyo al aprendizaje de los estudiantes y de la labor docente. Los y las docentes se han visto desafiados a experimentar soluciones innovadoras para mantener la comunicación con el estudiantado y sus familias. En muchos casos, estas últimas se han convertido, como no se había visto antes, en colaboradores indispensables del proceso educativo.

Por otra parte, desde la perspectiva curricular, varios Ministerios de Educación han optado por dotar al sistema de una mayor flexibilidad para abordar los contenidos de aprendizaje y la evaluación, introduciendo ajustes que permitan a los y las docentes priorizar aquellos aprendizajes considerados más relevantes o imprescindibles y favorecer 
procesos de evaluación formativa, que promuevan una mayor implicación con el propio aprendizaje y su mejora. Todas ellas, medidas que buscan disminuir los riesgos que las brechas y niveles de abandono se incrementen.

No cabe duda de que el impacto negativo de la pandemia está afectando a toda una generación de niños, niñas y adolescentes, cuya magnitud y efectos reales pese a todos los pronósticos no son visibles aún. La emergencia sanitaria se convirtió en una emergencia educativa. Por lo mismo, hoy más que nunca es necesario agotar todos los recursos y generar soluciones imaginativas que basadas en los principios de inclusión y equidad, resguarden que las medidas adoptadas por los países en sus intentos por llegar a la mayoría de los y las estudiantes, no dejen atrás a las minorías y a los grupos más vulnerables a la exclusión.

Los ejemplos antes mencionados, entre otros, son una señal de que las cosas se pueden hacer de manera distinta, el tiempo y las evidencias que se sigan acumulando de esta inédita experiencia, nos dirá si de las prácticas y lecciones aprendidas a propósito de esta emergencia educativa, las escuelas logren un mayor reconocimiento y valoración social, los estudiantes y sus familias hayan incorporado actitudes de autocuidado como también un mayor cuidado de su escuela. Estas cuenten con más autonomía y flexibilidad para gestionar los recursos, el curriculum y los aprendizajes; la confianza en la capacidad y compromiso de los profesores se haya fortalecido; la participación y trabajo colaborativo con las familias se haya mantenido y reforzado; y las tecnologías sean un recurso permanente de apoyo al aprendizaje y la enseñanza de uso generalizado en la Región.

En estos momentos difíciles no podemos permitirnos caer en el desánimo. Los sistemas educativos de América Latina partían de una situación de graves problemas de calidad y equidad educativas. Y todo indica que, con la pandemia, dicha situación se agravará. Sin embargo, hemos de ser optimistas, saldremos de ésta y, ojalá, salgamos reforzados. Si la sociedad y los diferentes poderes públicos entienden que la educación es un Derecho Humano básico que todos tenemos la obligación moral de cuidar y hacerla más inclusiva para todos y todas; y que los y las docentes son los verdaderos héroes y heroínas que llevan años luchando, no solo en esta difícil situación, para que haya una esperanza para millones de niños, niñas y adolescentes en situación de mayor desventaja de tener una vida mejor, ya se habrá conseguido mucho. Si de esta crisis conseguimos que se valore de verdad a la educación y a sus profesionales con hechos no solo con palabras, habrá esperanza.

\section{Referencias}

UNESCO. (2020). América Latina y el Caribe - Inclusión y educación: Todos y todas sin excepción. UNESCO.

Murillo, F. J. y Duk, C. (2020). El Covid-19 y las brechas educativas. Revista Latinoamericana de Educación Inclusiva, 14(1), 11-13. https://doi.org/10.4067/So718-73782020000100011 